\title{
Formation of Professional Orientation of High School Students to Medical Profession by Using ICT Tools
}

\author{
https://doi.org/10.3991/ijet.v15i01.11423 \\ Natalia M. Molodozhnikova $\left.{ }^{(}\right)$, Natalia V. Biryukova \\ I.M. Sechenov First Moscow State Medical University, Moscow, Russia \\ n.m.molodozhnikova@rambler.ru \\ Olga V. Galustyan \\ Southern Federal University, Rostov-on-Don, Russia \\ Julia B. Lazareva, Natalia N. Stroiteleva \\ I.M. Sechenov First Moscow State Medical University, Moscow, Russia
}

\begin{abstract}
The article is devoted to the formation of professional orientation of students to medical profession by using ICT tools. The article deals with the problem of professional orientation and formation of interest to the medical profession at schools with biological and medical classes. The use of ICT tools contributes to the integration of school subjects into current knowledge which are necessary for the future effective work of medical specialists. Application of ICT increases the effectiveness of professional orientational classes, improves students' awareness of their future profession, implements to the professional choice based on the awareness and understanding of students of their professional preferences and aptitudes. This technique makes it possible to form not only an adequate motivation to the medical profession, but also interest in disciplines connected with future profession.
\end{abstract}

Keywords—Professional orientation, medical profession, ICT tools, medical and biological classes, students.

\section{Introduction}

The problem of choosing a profession by young people has always been a focus of researchers' attention [3, 5, 20]. It is significant for solving the tasks of forming a professional focus on the medical profession. Analysis of the situation within the system of education of qualified medical personnel indicates difficult situation within the context of new world economic transformations. The way out of this situation is not only connected with the social and economic sphere but also with the development of psychological and pedagogical theory of vocational guidance.

Scientists [28, 30] consider that professional orientation of students serves as means of differentiation and individualization of education. Interests, inclinations and abilities of students should be taken into account due to the changes in structure, 
content and organization of the educational process. Conditions for the education should be created in accordance to the professional interests of students. Professional orientation of students is aimed at the implementation of student-centered education $[10,14,17]$.

Currently, one of the priorities of the education process is becoming informatization of education. This process provides educational sector with the methodology and practice of developing and optimizing the use of new information and communication technologies (ICT). It is significant that information and communication technologies implement a new educational paradigm.

Appropriate organization of the learning process, use of information and training resources, readiness and ability of teachers to work within the framework of new educational paradigm are necessary for the effective use of ICT within formation of professional orientation of high school students.

The pace of development of technologies, their fundamental changes during life of one generation require not only development of ICT tools but understanding that this process will be constant as well. That is why educational process is connected with the awareness of impossibility of getting education for all life and the necessity of the process of life-long learning [12, 27, 31].

Modern ICTs provide access, both to the teacher and the students to electronic sources of information (Internet, multimedia, electronic textbooks), which allow creative growth based on their use within the educational process. Use of ICT for educational purposes involves individualization of learning process based on interactivity and optimization of learning time.

Therefore, it is necessary to search for new forms, methods of organization and means of formation of professional orientation of high school students to medical profession.

\section{Methodology}

Formation of professional orientation of high school students to medical profession by using ICT tools has the following main objectives:

- Creation of conditions for a wide differentiation of the content of learning with the wide and flexible possibilities to build individual educational programs for students.

- Establishing equal access to ICT tools in accordance with the students' individual inclinations and needs.

- Expansion of opportunities for socialization of students by using ICT tools [2, 15, 19].

Professional training of a doctor is a complex system of professional development. There are several stages of medical education such as pre-university, university and postgraduate educational levels. Pre-university stage is significant in this chain, since professional orientation of a future doctor is carried out at this stage. 
The formation of interest (motivation) in learning at school is the first and the main stage in the theory of the systematic formation of mental actions and concepts. Presence of motivation to medical profession and to studying of the subjects which are necessary for the future profession activates all mental processes of a person [7, $22,29]$.

The presence of cognitive interest informs cognitive activity of strength, intensity, speed, relieves fatigue and improves its quality thereby. Raising interest to medical profession and to studying of academic disciplines is desirable and internally comfortable for students $[9,18,25]$.

However, the real state is unsatisfactory, which is connected with professional orientation and motivation towards the doctor's profession and, accordingly, the presence of adequate interests in studying subjects which are included in the medical training curriculum. It has a very negative effect on the quality of students' preparation and their internal mental discomfort which force on the learning process at medical university $[8,11]$.

\section{Materials and Methods}

Formation of professional orientation and adequate motivation of students for the medical profession was carried out within the electronic course "A Step to Medicine". This course included virtual excursions, involving visiting sites of I.M. Sechenov First Moscow State Medical University (University's Museum of Medical History, Botanical Garden, University departments) by high school students of medical and biological classes of lyceum. Lectures, seminars and master classes were held in video format by university lectures and professors. Students of biomedical classes were shown real working conditions of doctors and requirements of society to them.

A few lessons of electronic course "A Step to Medicine" were devoted to the historical and future development of medicine as a type of activity of certain eminent scientists in order to attract the students to the future medical profession. It was necessary to show that self-perfection, self-affirmation, achievement of a certain social status is possible only through deep mastery of professional skills and abilities, formation of creative abilities, etc. [16, 23, 24]. It required deep analysis of activity of outstanding specialists in the field of medicine and biology. Students could understand the prestige of this type of activity and their future social status, as well as they could change their initial value orientations of the profession, bringing it closer to what they needed only by understanding the true content of the doctor's (biologist's) work, its importance for preserving health of a human. It was important to show to the students that the only one true way to their self-assertion and selfimprovement was mastering this type of professional activity $[4,21,26]$. Thus, it was important to direct motivation of students in the right direction from the very beginning of their learning activity.

Therefore, students explored discoveries of outstanding scientists such as Ch. Darwin, G. Mendel, I. Sechenov, I. Mechnikov, T. Morgan and the others within the electronic course "A Step to Medicine". Lectures showed that these scientists 
achieved worldwide recognition only due to the persistent and dedicated work. However, the identity of doctor (biologist) needed not only good professional training. His/ her moral, ethical and aesthetic qualities such as empathy, selflimitedness, modesty, disinterestedness, honesty, goodwill, humanity, kindness, responsiveness, sense of beauty, responsibility, duty etc. were equally important for the future activities of a doctor. The central element of a formed deep and steady interest to the professional activity was doctor's sense of empathy $[1,6,13]$. We can speak of the formation of true professional interests in the medical profession if these qualities take place.

Students' learning activities were mainly focused on the social significance of the medical profession without a clear knowledge of the professional nature of future specialty activities, and, therefore, without a clear understanding of the scientific provisions significance on which this activity is carried out. That is why we included in the content of course of discipline "Biology" the following aspects and functional requirements:

- Revealing the role of the studied subject as necessary stage in the study of other disciplines (integration) and in mastering of medical profession.

- Emphasizing of relevance of the subject as a specific area of scientific knowledge for practical medicine based on the material of its historical and perspective development.

Formation of professional orientation high school students of medical and biological classes started with an introductory video lecture on biology. It was necessary to show that it was impossible to do qualitatively the work of a therapist, surgeon, pediatrician, gynecologist, etc. without knowledge of discipline "Biology". Connections of the discipline "Biology" with the profession of a doctor were shown within this lecture. Therefore, there can be no good doctor, researcher without knowledge of biology. Lecturers showed the importance of various sections of biology for theoretical and clinical medicine. Students were given the tasks to study the topics within discipline "Biology" and discuss them in a chat with their classmates. The head of the virtual discussion was a lecturer. Lecturer could appoint one of the students to be the coordinator of discussion after conducting 2-3 virtual discussions on professional topics in chart.

The following examples of topics of virtual discussions might serve as such an illustration:

- Genetic studies have allowed to develop methods for early diagnosis, treatment and prevention of human hereditary diseases.

- Selection of microorganisms allows to obtain enzymes, vitamins, hormones which are necessary for the treatment of different diseases.

- Genetic engineering allows to produce biologically active compounds and drugs, in particular, artificial creation of interferon within industrial conditions, etc.

These examples showed integration of biology to the disciplines of the medical university curriculum and the medical profession. Thus, internal motivation to the 
subject was formed, interest to medical profession is increased and adequate values for medical profession were brought up.

\section{$4 \quad$ Results}

Experimental work was carried out at I.M. Sechenov First Moscow State Medical University from 2017 to 2019. 157 high school students of medical and biological classes of lyceum of I.M. Sechenov First Moscow State Medical University participated in the study. Respondents were from 16 to 18 years of age. The experimental group consisted of 79 students. The content part of the experiment was represented by electronic course "A Step to Medicine". The control group included 78 students. They were trained within traditional face-to-face education.

We conducted a survey during which we interviewed high school students. We asked to answer a number of questions that allowed us to conclude concerning the awareness of the students of their future medical profession. The questionnaires were filled out by the students before the experimental work and after receiving primary knowledge and skills of profession. The results are presented in Table 1.

Table 1. The results of survey in control and experimental groups at the beginning and end of the experiment

\begin{tabular}{|l|c|c|c|c|}
\hline \multirow{2}{*}{ Indicators } & \multicolumn{2}{|c|}{ Before the experiment } & \multicolumn{2}{c|}{ After the experiment } \\
\cline { 2 - 5 } & $\begin{array}{c}\text { Experimental } \\
\text { group, \% }\end{array}$ & $\begin{array}{c}\text { Control group, } \\
\text { \% }\end{array}$ & $\begin{array}{c}\text { Experimental } \\
\text { group, \% }\end{array}$ & $\begin{array}{c}\text { Control group, } \\
\text { \% }\end{array}$ \\
\hline $\begin{array}{l}\text { Students have an idea of a professional } \\
\text { activity of medic }\end{array}$ & 43,6 & 44,2 & 80,1 & 44,8 \\
\hline $\begin{array}{l}\text { Students name mental properties which } \\
\text { are important for the successful } \\
\text { implementation of professional activities } \\
\text { of medic }\end{array}$ & 38,4 & 42,2 & 86,6 & \multirow{2}{*}{43,2} \\
\hline $\begin{array}{l}\text { Students name psychological qualities } \\
\text { incompatible with the profession of } \\
\text { medic }\end{array}$ & 46,9 & 47,4 & 84,1 & \\
\hline $\begin{array}{l}\text { Students indicate the competencies } \\
\text { necessary for the successful activity of } \\
\text { medic }\end{array}$ & 43,7 & 44,3 & 91,4 & 50,7 \\
\hline
\end{tabular}

The results from Table1 reveal that students' ideas about their future medical profession were less than $50 \%$ in experimental group and in control group at the beginning of the experiment. The indicators increased in experimental group after the experimental work significantly. The results in the control group didn't change significantly.

It confirms our assumption that formation of professional orientation of high school students to medical profession by using ICT tools has a positive impact on the formation of professional self-determination of a young person. It should be carried out throughout the entire period of his / her professional development. 
We also measured the level of knowledge of the discipline "Biology" in experimental group and in control group at the beginning and at the end of the experimental work. Knowledge of the discipline "Biology" was evaluated according to the grading scale (low level was from 60 to 70 points; medium level was from 71 to 85 points; high level was from 86 to 100 points).

Table 2. The results of knowledge of discipline "Biology" in control and experimental groups at the beginning and end of the experiment

\begin{tabular}{|l|c|c|c|c|}
\hline \multirow{2}{*}{ Level } & \multicolumn{2}{|c|}{ Before the experiment } & \multicolumn{2}{c|}{ After the experiment } \\
\cline { 2 - 5 } & $\begin{array}{c}\text { Experimental group, } \\
\text { \% }\end{array}$ & Control group, \% & $\begin{array}{c}\text { Experimental } \\
\text { group, \% }\end{array}$ & $\begin{array}{c}\text { Control group, } \\
\text { \% }\end{array}$ \\
\hline Low & 42,3 & 44,5 & 10,7 & 37,6 \\
\hline Medium & 35,1 & 36,7 & 33,9 & 38,3 \\
\hline High & 22,6 & 18,8 & 55,4 & 24,1 \\
\hline
\end{tabular}

Comparative analysis of the results of input and final diagnostics of knowledge of discipline "Biology" in control and experimental groups showed a significant positive dynamic in experimental groups, which indicates the effectiveness of the experimental work.

\section{Conclusion}

Formation of professional orientation of high school students to the medical profession by using ICT tools includes implementation of the professional component within the educational subjects, which is taking into account information of practical activities of doctor; application of ICT tools (electronic course "A Step to Medicine", lectures, seminars and master classes in video format, virtual discussions on professional topics in chart, etc.). We conclude that the increase of the efficiency of lessons on professional orientation of students to the medical profession is connected with the use of ICT, which has an ability to increase informational density of lessons. ICT require understanding of the didactic specificity of educational material. Use of ICT tools in education can have a tangible effect only when lecturers and professors have an opportunity to use ICT systematically.

Today, the use of ICT within the educational process has become an integral part of it. Introduction of ICT tools into research and laboratory activities of high school students develop their independent and creative activity. Effective use of information and communication technologies allows to implement a fundamentally new approach to education, which is based on broad communication, convergence, free exchange of views, ideas, information of the participants of educational process; natural desire to broaden their horizons. It is also is based on real research methods which allow to learn the laws of nature, social phenomena in their dynamics, in the process of solving vital problems, as well as features of various types of creativity in the process of activity of high school students. It initiates the development of natural education, focuses on the moral aspects of life and human activity; promotes the acquisition by teachers and students of a variety of related skills that can be very useful in life. 
Thus, formation of professional orientation of students to the medical profession by using ICT tools will have a favorable impact on adaptation to the conditions of study at university.

\section{References}

[1] Allos, B. M., Yakes, E. A., Fleming, A., Cutrer, W. B., Pilla, M., Clair, W., Miller, B. (2018). Framing medicine as a moral practice: An introductory medical school course. Academic Medicine, 93(9), 1310-1314.https://doi.org/10.1097/ACM.0000000000002301

[2] Brown, T., Williams, B., \& Lynch, M. (2013). Relationship between clinical fieldwork educator performance and health professional students' perceptions of their practice education learning environments. Nursing and Health Sciences, 15(4), 510-517. https://doi.org/10.1111/nhs.12065

[3] Bubnov, Y. A., Gaidar, K. M., Fedorov, V. A., Berezhnaya, I. F., \& Galustyan, O. V. (2018). Organization of the training process based on modular and rating technology at higher educational institution. Espacios, 39(25)

[4] Buchholz, M. B. (2017). On the status of professional psychotherapy: After DSM-5, neurohype and RCT dominance. [Zur Lage der professionellen Psychotherapie: Nach DSM-5, Neurohype und RCT-Dominanz] Forum Der Psychoanalyse, 33(3), 289-310. https://doi.org/10.1007/s00451-017-0260-4

[5] Çitaku, F., Violato, C., Beran, T., Donnon, T., Hecker, K., \& Cawthorpe, D. (2012). Leadership competencies for medical education and healthcare professions: Populationbased study. BMJ Open, 2(2) https://doi.org/10.1136/bmjopen-2012-000812

[6] Dashash, M. (2013). Community-oriented medical education: Bringing perspectives to curriculum planners in Dmascus University. Education for Health: Change in Learning and Practice, 26(2), 130-132. https://doi.org/10.4103/1357-6283.120708

[7] Denis, J., \& Van Gestel, N. (2016). Medical doctors in healthcare leadership: Theoretical and practical challenges. BMC Health Services Research, 16(2) https://doi.org/10. $\underline{1186 / \mathrm{s} 12913-016-1392-8}$

[8] Dinu, C. E., \& Dinu, A. L. (2011). Medical profession vocation and contextuality. European Journal of Science and Theology, 7(4), 67-74.

[9] Eileen, M., Peter, G., Bernadette, J., Lindsay, M., \& Christine, B. (2017). Crossing professional cultures: A qualitative study of nurses working in a medical school. Contemporary Nurse, 53(6), 633-646.https://doi.org/10.1080/10376178.2017.1416304

[10] Ellaway, R. H., Cooper, G., Al-Idrissi, T., Dubé, T., \& Graves, L. (2014). Discourses of student orientation to medical education programs. Medical Education Online, 19(1) https://doi.org/10.3402/meo.v19.23714

[11] Elvey, R., Hassell, K., \& Hall, J. (2013). Who do you think you are? Pharmacists' perceptions of their professional identity. International Journal of Pharmacy Practice, 21(5), 322-332. https://doi.org/10.1111/ijpp.12019

[12] Galustyan, O. V., Borovikova, Y. V., Polivaeva, N. P., Kodirov, B. R., \& Zhirkova, G. P. (2019). E-learning within the field of andragogy. International Journal of Emerging Technologies in Learning, 14(9), 148-156.https://doi.org/10.3991/ijet.v14i09. $\underline{10020}$

[13] Galustyan, O. V., Gaidar, K. M., Aleshina, S. A., Ksenofontova, A. N., \& Ledeneva, A. V. (2018). Development of group subjectivity of pupils within collaborative activities. TEM Journal, 7(4), 854-858. doi:10.18421/TEM74-25 
[14] Galustyan, O. V., Lazukin, V. F., Petelin, A. S., \& Ostapenko, V. S. (2018). Diagnostic Activity of Teachers at High School. Revista Espacios, Vol. 39(N 10). Retrieved from http http://www.revistaespacios.com/a18v39n10/18391024.html

[15] Hylin, U., Lonka, K., \& Ponzer, S. (2011). Students' approaches to learning in clinical interprofessional context. Medical Teacher, 33(4), e204-e210. https://doi.org/10.3109/ $\underline{0142159 X .2011 .557410}$

[16] Jawaid, S. A., \& Jawaid, M. (2018). How to ensure effective use of media to communicate with healthcare professionals and general public. Pakistan Journal of Medical Sciences, 34(5), 1054-1057. https://doi.org/10.12669/pjms.345.16172

[17] Jayakrishnan, T., Honhar, M., Jolly, G. P., Abraham, J., \& Jayakrishnan, T. (2012). Medical education in India: Time to make some changes. National Medical Journal of India, 25(3), 164-167.

[18] Jorbenadze, T., Shakarashvili, M., Jikia, I., \& Khvichia, N. (2011). Professional orientation of medical students--personal training (review). Georgian Medical News, (198), 55-62.

[19] Komarova, E.P., Fetisov, A. S., Larina, T.V., \& Galustyan, O.V. (2017). The Development of Physical Training Culture of a Personality. Revista Espacios, Vol. 38(N 50). Retrieved from http://www.revistaespacios.com/a17v38n50/17385028.html

[20] Kravchenko E.V., Galustyan O.V, Kovtunenko L.V., \& Kolosova L.A. (2018). Pedagogical Practice of Students. Revista Espacios, Vol. 39 (N 17). Retrieved from http://www.revistaespacios.com/a18v39n17/18391731.html

[21] Křžova, E. (2016). Medical student's main motivation is to help people - yet. [Hlavní motivací mediků je pomáhat lidem - Zatím] Prakticky Lekar, 96(2), 88-90.

[22] Mayta-Tristán, P., Pereyra-Elías, R., Montenegro-Idrogo, J. J., Mejia, C. R., Inga-Berrospi, F., \& Mezones-Holguín, E. (2017). Profile and professional expectations of medical students from 11 Latin American countries: The red-LIRHUS project. BMC Research Notes, 10(1) https://doi.org/10.1186/s13104-017-2479-y

[23] McDonald, R. (2013). 'Bourdieu', medical elites and 'social class': A qualitative study of 'desert island' doctors. Sociology of Health \& Illness, 36(6), 902-916. https://doi.org/10.1111/1467-9566.12121

[24] McKenna, B. (2010). Take back medical education-the "primary care" shuffle. Medical Anthropology: Cross Cultural Studies in Health and Illness, 29(1), 6-14. https://doi.org/10.1080/01459740903517246

[25] Michelsen, S., Vabø, A., Kvilhaugsvik, H., \& Kvam, E. (2017). Higher education learning outcomes and their ambiguous relationship to disciplines and professions. European Journal of Education, 52(1), 56-67. https://doi.org/10.1111/ejed.12199

[26] Morokhovets, H. Y., Uvarkina, O. V., Bieliaieva, O. M., Lysanets, Y. V., Senkevych, H. A., \& Stetsenko, S. A. (2019). Development of motivation towards education in medical students. Wiadomosci Lekarskie (Warsaw, Poland: 1960), 72(1), 7-11.

[27] Novak, M. K., Palladino, C., Ange, B., \& Richardson, D. (2014). Measuring health professions students' orientation toward lifelong learning. Journal of Allied Health, 43(3), 146-149.

[28] Park, H. J. (2011). The concept of medical professionalism as for self-employed physicians in Korea. Journal of the Korean Medical Association, 54(11), 1154-1163. https://doi.org/10.5124/jkma.2011.54.11.1154

[29] Salamonson, Y., Everett, B., Koch, J., Wilson, I., \& Davidson, P. M. (2009). Learning strategies of first year nursing and medical students: A comparative study. International Journal of Nursing Studies, 46(12), 1541-1547. https://doi.org/10.1016/j.ijnurstu. $\underline{2009.05 .010}$ 
[30] Volpe, R. L., Hopkins, M., Haidet, P., Wolpaw, D. R., \& Adams, N. E. (2019). Is research on professional identity formation based? Early insights from a scoping review and metasynthesis. Medical Education, 53(2), 119-132.https://doi.org/10.1111/medu.13781

[31] Whetton, S., \& Hazlitt, C. (2015). Educating the health informatics professional: The impact of an academic program. https://doi.org/10.3233/978-1-61499-558-6-159

\section{Authors}

Natalia M. Molodozhnikova is Associate Professor of the Department of Biology and General Genetics of I.M. Sechenov First Moscow State Medical University (Sechenov University), Moscow, Russia. Email: n.m.molodozhnikova@ @ambler.ru

Natalia V. Biryukova is Director of the Resource Center "Medical Sechenov PreUniversity" of I.M. Sechenov First Moscow State Medical University (Sechenov University), Moscow, Russia.

Olga V. Galustyan is Professor of the Department of Education and Pedagogical Sciences of Southern Federal University, Rostov-on-Don, Russia.

Julia B. Lazareva is Associate Professor of the Department of Biology and General Genetics of I.M. Sechenov First Moscow State Medical University (Sechenov University), Moscow, Russia.

Natalia N. Stroiteleva is Senior Lecturer of the Department of Biology and General Genetics of I.M. Sechenov First Moscow State Medical University (Sechenov University), Moscow, Russia.

Article submitted 2019-08-02. Resubmitted 2019-09-20. Final acceptance 2019-09-21. Final version published as submitted by the authors. 